IDEA - Studia nad strukturą i rozwojem pojęć filozoficznych $\mathrm{XXVIII/2}$

\title{
ALICJA KISIELEWSKA
}

(Bialystok)

\section{SERIALE TELEWIZYJNE JAKO WSPÓLNOTY SYMBOLICZNE}

Według Ernsta Cassirera „kiedy człowiek po raz pierwszy zwrócił oczy ku niebiosom, nie uczynił tego jedynie dla zaspokojenia intelektualnej ciekawości. W rzeczywistości człowiek szukał w niebiosach swego własnego odbicia i porządku ludzkiego wszechświata" ${ }^{\prime}$. Spragniony rozumienia świata człowiek współczesny często zwraca się ku mediom, a zwłaszcza ku telewizji, gdzie szuka go w przekazach telewizyjnych. W zachodnich społeczeństwach telewizja relatywnie szybko stała się zintegrowana $z$ rutyną życia codziennego ${ }^{2}$. W symbolicznej i rytualnej konstrukcji życia codziennego telewizja odgrywa zasadniczą rolę ogniskując domową konwersację, sytuując odbiorców w lokalnych, narodowych i globalnych relacjach społecznych, a także dostarczając im informacji i rozrywki ${ }^{3}$. Telewizja, zdaniem Janusza Bohdziewicza, stała się „symbolem naszego świata i naszych czasów”. Oznacza to „nieustannie próbować rozumieć ów świat i czasy za jej pośrednictwem - być-w-świecie-przez-telewizję". Przy czym

${ }^{1}$ E. Cassirer, Esej o cztowieku. Wstęp do filozofii kultury, przet. A. Staniewska, Czytelnik, Warszawa 1998, s. 101.

${ }^{2}$ N. Abercombie, Television and Society, Polity Press, Cambridge, 1997, s. 168.

${ }^{3}$ Tamże, s. 169.

${ }^{4}$ J. Bohdziewicz, Piekno aktualności.Telewizja bycia u progu czasu, NCN, Warszawa 2014, s. 184. 
podobnie jak niejednolity jest otaczający nas świat, w którym trudno o jedność sensu, tak też w telewizji mamy do czynienia $\mathrm{z}$ wieloma jego wizjami. Są one zależne od różnych i różnorodnych czynników: od stacji telewizyjnej, jej ideologii, strategii komercyjnej, stylu wyrażającego się w ramówce telewizyjnej, ale też od różnych sposobów interpretowania przekazów przez widzów. Telewizja dzisiaj, w dobie wielokanałowej satelitarnej telewizji cyfrowej, mówi widzom nie tyle o czym mają myśleć, a raczej o czym mogą myśleć, a dzięki różnego rodzaju stosowanym dyskursom, jak mogą myśleć ${ }^{5}$. Z opisywanych przez Cassirera form symbolicznych, takich jak: język, mit, religia, sztuka ${ }^{6} \mathrm{w}$ telewizji występują wszystkie. Telewizja tworzy środowisko symboliczne, zaś kluczem do jego zrozumienia jest proces symboliczny, czyli używanie symboli w komunikacji i interpretacja ich sensów ${ }^{7}$.

Przedmiotem namysłu w niniejszym tekście będą seriale telewizyjne ujmowane jako wspólnoty symboliczne. W sposób szczególny przyjrzę się bohaterom seriali uosabiającym mity telewizyjne wpisane w szerszy symboliczny proces telewizyjnych mitologii. Specyficzną cechą narracji telewizyjnych, jak podkreśla Sara Kozloff, jest fundamentalne znaczenie postaci ${ }^{8}$, które występują na ekranie jako konkretne osoby, wyróżniające się osobowości charakteryzujące się określonym zestawem działań, językiem, sposobem zachowania w relacjach międzyludzkich. Bohaterowie seriali telewizyjnych, aby stali się wyrazicielami zbiorowych mitów, powinni prezentować określone wartości, które mogą stać się bliskie odbiorcom. Ponadto powinni odpowiadać na nieuświadamiane potrzeby widzów - wyrażać ich pragnienia, lęki i obsesje, ale także pokazywać, jak odnajdywać się w życiu codziennym.

Seriale ujmowane jako opowieści telewizyjne posiadają szczególne mitotwórcze właściwości, ponieważ dostarczają widzom przykłady etosu we współczesnym świecie, wzory postaw stanowiące punkty odniesienia do rzeczywistych

${ }^{5}$ Por. R.C. Wstęp, [w:] Teledyskursy. Telewizja w badaniach wspótczesnych, pod red. R. C. A1lena, przeł. E. Stawowczyk, Wydawnictwo Szumacher, Kielce 1998, s. 20; J. Bohdziewicz, dz. cyt., s. 182.

${ }^{6}$ E. Cassirer, dz. cyt., s. 126.

${ }^{7}$ J. Bohdziewicz, dz. cyt., s. 183.

${ }^{8}$ S. Kozloff, Teoria narracji a telewizja, [w:] Teledyskursy..., wyd. cyt., s. 76. 
relacji międzyludzkich, a także wiarę w jakiś totalny sens wyrażającą się na przykład w przekonaniu o konieczności happy endu. Mitotwórcze cechy opowiadań telewizyjnych wiążą się także $z$ nieuchwytnością postaci narratora, który może się kojarzyć z jakąś „siłą wyższą” niejako odgórnie dającą widzom daną opowieść. Ten aspekt dotyczący mitów codzienności wiąże się z koncepcją mitu jako rzeczywistości „konstruowanej”. W tym kontekście działanie mitów kultury masowej w sposób przenikliwy analizował Roland Barthes, który ujmował mit jako system porozumiewania się - komunikat, który jest „sposobem znaczenia, jest formą" . Zdaniem autora mitem może być wszystko, istotny jest tutaj sposób wypowiadania. Barthes sprzeciwiał się ujmowaniu mitu jako kłamstwa. „Mit niczego nie ukrywa i niczego nie ujawnia: mit zniekształca; mit nie jest ani kłamstwem, ani wyznaniem: jest naginaniem"10. Jest, zdaniem autora, rodzajem kompromisu, który umożliwi niejako narzucenie pożądanego pojęcia. Mit rozumiem tutaj w sensie Barthesowskim jako sztucznie, czyli medialnie skonstruowaną opowieść, która naturalizuje rzeczywistość, czyniąc ją tym samym oczywistą i zrozumiałą. Mity kultury masowej mają charakter narzucający się, imperatywny. Barthes podkreśla, że stanowią one rodzaj „kradzieży języka”, ponieważ zafałszowują obraz rzeczywistości. „To zawsze tak było” - mit jest zasadą rozumienia zdarzeń zakładającą niejako „naturalny”, czyli pozaczasowy, zbiór wymagań. Ponieważ człowiek nie szuka w nim informacji o świecie w którym żyje, ale własnego miejsca we wspólnocie wartości. W kulturze współczesnej mamy do czynienia $z$ wszechobecnością mitu i różnego rodzaju praktyk mitologizacyjnych. Ernst Cassirer mówił, że „mit, choć jest tworem fikcyjnym, nie jest fikcją świadomą, lecz nieświadomą" ${ }^{11}$. Podkreślał także, że „prawdziwym podłożem mitu nie jest podłoże myśli, lecz uczucia”12. „Mit wyrasta z podłoża emocjonalnego i to podłoże nadaje wszystkim jego tworom swoje własne, specyficzne zabarwienie" ${ }^{\prime 13}$. Niewątpliwie twórcy telewizyjni wykorzystują wskazane przez

\footnotetext{
${ }^{9}$ Roland Barthes, Mitologie, przeł. A. Dziadek, Wyd. KR, Warszawa 2000, s. 239.

${ }^{10}$ Tamże, s. 261.

${ }^{11}$ E. Cassirer, dz. cyt., s. 140.

${ }^{12}$ Tamże, s. 150.

${ }^{13}$ Tamże, s. 152.
} 
Cassirera cechy mitu kreując mity serialowe na bazie mitów tkwiących w pokładach świadomości zbiorowej i wykorzystując ich uczuciowy potencjał. Tworzeniu serialowych mitów i różnego rodzaju mitologizacji sprzyjają także cechy gatunkowe serialu, takie jak: ciągłość narracyjna trwająca często kilka sezonów, a teoretycznie w nieskończoność, powtarzalność wątków, motywów, postaci. Najbardziej wyrazistymi mitycznymi konstrukcjami symbolicznymi są serialowi bohaterowie, ponieważ angażują oni widzów w trwający, dynamiczny proces budowania postaci rozwijającej się z odcinka na odcinek, a także poprzez luki w obrębie odcinków zarówno w czasie ekranowym, jak i czasie opowiadania. Widzowie mogą obserwować, jak postać zmienia się od pierwszego sezonu do ostatniego, ale jak podkreśla Jason Mittell, większość telewizyjnych bohaterów są to jednostki raczej spójne niż zmienne, nawet jeśli przeżywają one wiele zmian w życiu, postać jest zazwyczaj stabilna, raczej akumuluje ona doświadczenia narracyjne niż podlega wskutek nich zmianom ${ }^{14}$.

Wychodząc z założenia, że seriale stanowią symboliczne wspólnoty należy zauważyć, że naszą przestrzeń symboliczną zaludniają bohaterowie nie tylko polskich seriali, ale też zagranicznych, zwłaszcza najpopularniejszych - amerykańskich. Przedmiotem namysłu w niniejszym tekście będą obecne na polskim rynku medialnym seriale telewizyjne powstałe od drugiej połowy lat 90. XX wieku do dzisiaj: amerykańskie i polskie. Będą to uznane za znaczące w światowej produkcji seriale amerykańskie, które były wyświetlane w Polsce przez stacje niekodowane, a tym samym zyskały szerszy społeczny odbiór, a także najpopularniejsze seriale polskie. W Polsce nie ma znaczącej produkcji serialowej stacji kablowych i satelitarnych. Najważniejszymi producentami seriali są dwa kanały telewizji publicznej: TVP1 i TVP2 oraz stacje komercyjne: Polsat i TVN.

Interesują mnie tutaj serialowi bohaterowie, którzy stali się w Polsce bohaterami zbiorowej wyobraźni. Ujmując serialowych bohaterów jako konstrukcje symboliczne tworzące zmityzowanych bohaterów naszych czasów spróbuję zastanowić się nad znaczeniami, jakie oni niosą. Biorąc pod uwagę materiał sym-

${ }^{14}$ J. Mittell, Complex TV. The Poetics of Contemporary Television Storytellins, New York University Press, New York and London 2015, s. 132-133. 
boliczny, jakim się posłużono $\mathrm{w}$ serialu, konwencje jego prezentacji, symboliczną obróbkę rzeczywistości dokonaną przez stację telewizyjną adresującą swoje produkty do pewnej, zakładanej widowni, a także symboliczne przepracowywanie treści serialowych przez widzów przyjrzę się wartościom, jakie pragną przekazywać stacje telewizyjne produkujące seriale. Szczególne miejsce w galaktyce serialowych bohaterów wyobraźni zbiorowej przełomu XX i XXI wieku, nie tylko w Polsce, zajmuje Tony Soprano (James Gandolfini) mafijny boss z New Jersey, główny bohater serialu Rodzina Soprano. W telewizji uważanej z medium „rodzinne” przez długi czas nie było miejsca na bohatera gangstera. Serial Rodzina Soprano wyprodukowany i nadawany przez kodowany kanał HBO (19992007; 6 sezonów) to zmienit. Tony Soprano i jego rodzina wkroczyli również do Polski. Serial był u nas emitowany od 1999 r. na płatnym kanale HBO, a od 2001 zaczęła go nadawać stacja TVN ${ }^{15}$. Niewątpliwie istotne jest tutaj, że serial łączył dwie klasyczne hollywoodzkie formuły: sagę rodzinną i dramat mafijny ${ }^{16}$. O tym, że amerykański gangster Tony Soprano zyskał uznanie także polskich widzów zadecydowało kilka czynników, przede wszystkim, jak sądzę, zastosowany przez twórców scenariusz rodzinny. Tony Soprano uosabia wzór „gangstera drobnomieszczanina”, który oprócz swojej „profesji” jest mężem i ojcem. Ma żonę i dwoje dzieci, troszczy się o rodzinę i zgodnie ze swoim „oficjalnym” statusem społecznym mieszka w domu na przedmieściach. Poza tym mafia przedstawiona $\mathrm{w}$ serialu przypomina przedsiębiorstwo, które przede wszystkim powinno przynosić zysk członkom „rodziny”. Ale najistotniejsze z punktu widzenia odbiorców jest to, że Tony Soprano stanowi postać wielowymiarową. Aby przybliżyć widzom bohatera-gangstera producenci wykreowali postać Ton'ego jako „gangstera w kryzysie”, który miewa ataki paniki, cierpi na depresję i regularnie poddaje się psychoterapii. Ponadto przydali mu cechy typowego męża

\footnotetext{
${ }^{15} \mathrm{http} / / /$ www.newsweek.pl/kultura/wiadomosci-kulturalne/mefisto-z-kompleksami,29579, 1,1.html (27.08.2016).

${ }^{16}$ Każdej niedzieli Rodzina Soprano przyciągała przed telewizory co najmniej osiem milionów Amerykanów, a w kolejnych sezonach popularność serialu rosła. Jego oglądalność wynosiła nawet 13,4 miliona widzów na odcinek. Serial odniósł niebywały sukces zyskując miano serialu wszech czasów. Symbolem jego popularności był plakat reklamujący jego czwarty sezon przedstawiający tylko zdjęcia bohaterów bez tytułu serialu.
} 
i ojca, który ma problemy rodzinne: z żoną i z dziećmi, a także przeżywa kryzys tradycyjnej męskości. Dzięki takim zabiegom mafia przedstawiona w Rodzinie Soprano odbijała problemy amerykańskiej klasy średniej przełomu XX i XXI wieku, a postać Tony'ego Soprano stanowiła tego egzemplifikację ${ }^{17}$. Paradoksalnie serial i jego bohater wpisywali się także w problemy społeczne modernizującej się Polski, w której klasa średnia dopiero zaczynała się tworzyć.

Równie popularna, jak Tony Soprano, w tym czasie była w Polsce para agentów specjalnych FBI: Mulder i Scully, bohaterów serialu $Z$ Archiwum $X$ wyprodukowanego przez stację FOX w latach 1993-2002 (9 serii oraz 1 miniseria). W Polsce serial był wyświetlany od 1996 roku w TVP2 i w Polsacie ${ }^{18}$. Mulder (David Duchovny) i Dana Scully (Gillian Anderson) prowadzą tytułowe Archiwum X będące komórką Federalnego Biura Śledczego, do której trafiają niewyjaśnione sprawy kryminalne. Widzów bardziej niż rozwiązywane w serialu zagadki kryminalne interesowała jednak nietypowa para agentów FBI. Agent specjalny Mulder wierzący w istnienie istot pozaziemskich i różnych niewytłumaczalnych zjawisk stanowił zaprzeczenie społecznych wyobrażeń na temat agenta FBI. Sama praca w Archiwum X była dla niego próbą wyjaśnienia zagadki zaginięcia jego siostry, która - jak sądził Mulder - została porwana przez „obcych”. Natomiast Scully stanowiła jego przeciwieństwo, reprezentowała w tym duecie naukowy racjonalizm i była sceptycznie nastawiona do wszelkich badanych przez nich spraw. Główni bohaterowie Mulder i Scully żyją głównie pracą, są profesjonalistami, chociaż reprezentują różne koncepcje profesjonalizmu. Ceną, jaką płacą za osiągnięcia w pracy zawodowej, w tym wypadku śledczej, jest bark ustabilizowanego życia rodzinnego. Twórcy serialu $Z$ archiwum $X$ kreują nowy mit detektywa-agenta jako człowieka poszukującego prawdy. Powstaje on wskutek połączenia cech dwojga bohaterów: swego rodzaju irra-

${ }^{17}$ J. Majmurek, Mafia jako small business, [w:] Seriale. Krytyka Polityczna, Wyd. Krytyki Politycznej, Warszawa-Gdańsk 2010, s. 165-167.

${ }^{18}$ W Polsce $Z$ archiwum $X$ wyświetlane było od 20 marca 1996 r. na antenie stacji TVP2 (seria 1-7). W międzyczasie telewizja Polsat zakupiła prawa do kilku pierwszych serii. W styczniu 2004 r. w TVP2 wyemitowano ósmą serię. Dziewiąty, ostatni sezon (2001-2002) w Polsce zadebiutował 6 maja 2013 r. na kanale Tele 5. Oprócz tego abonenci telewizji kablowych mogą/mogli oglądać serial. 
cjonalizmu Muldera i sceptycznego, naukowego racjonalizmu Scully. W serialu prowadzi to do szerszej refleksji na temat dwóch możliwych wizji rzeczywistości: dominującej w naszej kulturze, uznanej za racjonalną i drugiej dopuszczającej możliwość istnienia w świecie elementów niewytłumaczalnych, nieracjonalnych. Wątpliwości tego rodzaju były szczególnie bliskie, także polskim, widzom na przełomie XX i XXI wieku.

Inni mityczni bohaterowie, a właściwie bohaterki amerykańskich seriali przełomu wieków, które wpisały się w zbiorowe wyobrażenia polskich widzów to kobiety wyzwolone, singielki i profesjonalistki. Jedną z nich jest Ally McBeal (Calista Flockhart) młoda prawniczka, bohaterka serialu o tym samym tytule produkowanego w latach 1997-2002 (5 sezonów) przez stację Fox. Serial, który był oglądany w USA przez dziesieciomilionową widownię, za sprawą jego bohaterki wkrótce stał się tematem artykułów w największych amerykańskich czasopismach i dziennikach ${ }^{19}$. W Polsce był on emitowany w latach 1998-2003 (Polsat, TVN7). Powód zainteresowania mediów serialem stanowił nowy wzorzec postaci kobiecej w nim zaprezentowany. Ally McBeal pracowała w fikcyjnej bostońskiej kancelarii prawniczej i świetnie sobie radziła na sali sądowej. Novum polegało na tym, że profesjonalizm bohaterki podszyty był seksualnością, którą wykorzystywała ona w wielu sytuacjach, także zawodowych. Przebojowy serial wywołał dyskusję na temat pozycji kobiety we współczesnym społeczeństwie. $Z$ jednej strony w kontekście pojawienia się tzw. trzeciej fali feminizmu radykalnie nastawione feministki twierdziły, że serial, a zwłaszcza jego główna bohaterka stanowiła zaprzeczenie tego, o co walczył ruch feministyczny w poprzednich latach. A drugiej strony „tytułowa postać serialu uznana została, za przełamujący lody postfeministyczny hymn pochwalny dla wizerunku nowej kobiety lat 90., choć rzeczywiście podobizna ta daleka była od klasycznie pojmowanych postulatów emancypacyjnych"20. W postaci Ally McBeal jest pewna dwoistość, która być może zadecydowała o jej popularności, nie tylko wśród widzów ame-

${ }^{19}$ Por. A. Lewicki, Allymacbealizm po polsku, [w:] Polskie seriale telewizyjne, pod red. P. Zwierzchowskiego, B. Gizy, J. Batesa, K. Kosińskiej, Wydawnictwo Uniwersytetu Kazimierza Wielkiego, Bydgoszcz 2014, s. 164.

${ }^{20}$ A. Lewicki, dz. cyt., s. 164. 
rykańskich. $Z$ jednej strony jest ona wzorem profesjonalistki, kobiety wyzwolonej, ale jednocześnie ma tradycyjnie kobiece pragnienie znalezienia miłości swojego życia.

Równie, jak Ally McBeal wzorcotwórczymi bohaterkami wpisującymi się w postfeministyczny model kobiety były cztery przyjaciółki, mieszkanki Manhattanu, główne bohaterki komediowego serialu Seks w wielkim mieście: Carrie Bradshow (Sarah Jessica Parker) dziennikarka-freelancerka pisująca do nowojorskich gazet, miłośniczka mody, a zwłaszcza butów; Miranda Hobbes Brady (Cynthia Nixon) - prawniczka; Charlotte York McDougal (Kristin Davis) marszandka i Samantha Jones (Kim Cattrall) - właścicielka agencji PR. Seks w wielkim mieście został wyprodukowany w latach 1998-204 (6 serii) przez stację HBO na podstawie bestsellerowej książki Candace Bushnell Sex and the City ${ }^{21}$. Narratorką serialu była Carrie Bradshow, która pisała co tydzień dla fikcyjnej gazety „New York Star” kolumnę zatytułowaną „Seks w wielkim mieście”. Skupiała się w niej na doświadczeniach seksualnych swoich i najbliższych przyjaciółek. Główne bohaterki Seksu w wielkim mieście stały się niemal egzemplarycznymi figurami wykształconych, wyzwolonych singielek, które inspirowały kobiety na całym świecie, nie tylko w zakresie mody, ale też stylu życia. Zostały one uznane za symbole nowego modelu kobiecości polegającego na swobodzie seksualnej i spełnianiu swoich pragnień.

Swego rodzaju kontynuację wzoru, jaki prezentowały bohaterki Seksu w wielkim mieście, możemy odnaleźć w serialu Desperate Housewives, w dosłownym thumaczeniu „zdesperowane gospodynie domowe” wyprodukowanym przez familijną stację ABC w latach 2004-2012 (8 serii). W Polsce pojawił się on pod tytułem Gotowe na wszystko w 2005 roku i był emitowany w Polsacie. Bohaterki Gotowych na wszystko są starsze od bohaterek Seksu w wielkim mieście, mają około czterdziestu lat, można więc założyć, że w pewnym sensie pokazują ich kolejny etap życia. Są nimi cztery przyjaciółki, sąsiadki mieszkające na luksusowym przedmieściu fikcyjnego miasta Fairview, przy ulicy Wisteria Lane ${ }^{22}$. Na po-

\footnotetext{
${ }^{21}$ W Polsce Seks w wielkim mieście nadawały stacje, m.in.: TVP2, TVN, TVN7, TVN Style.

${ }^{22}$ Bree van de Kamp (Marcia Cross), protestantka, na zewnątrz ideał gospodyni domowej, żona chirurga, matka dwójki dzieci, Gabrielle Solis (Eva Longoria), katoliczka, była modelka, żo-
} 
czątku serialu było ich pięć, ale Mary Alice Young w pierwszym odcinku popełniła samobójstwo i w dalszej części serialu jej koleżanki próbowały dociec, co było tego powodem. Mary Alice pełniła w serialu funkcje narratorki przemawiającej z zaświatów. Przedmiot serialowej kreacji stanowił zdekonstruowany mit gospodyni domowej, a także mityczne wyobrażenie idyllicznych i zasobnych amerykańskich przedmieść wykreowane, między innymi, przez amerykańskie seriale telewizyjne ${ }^{23}$. W Desperate Housewives źródłem problemów z tradycyjnie rozumianą kobiecością było „nieperfekcyjne” doświadczenie „pań domu”24 i wiążąca się z nim dekonstrukcja tradycyjnego wyobrażenia kobiecości dotycząca kwestii płci i związanej z nią atrakcyjności seksualnej, macierzyństwa, prowadzenia domu.

Osobnym fenomenem telewizyjnym i szerzej kulturowym są cieszące się powodzeniem od pół wieku amerykańskie seriale medyczne, w których znajdujemy zmityzowanego bohatera w osobie lekarza. Poprzez przedstawianie postaci lekarza i jego środowiska twórcy seriali medycznych w pewien sposób prezentowali w nich obraz amerykańskiego społeczeństwa - realnego lub wykreowanego $^{25}$. Głównym bohaterem nowego i niezwykle popularnego serialu medycznego produkowanego dla stacji Fox w latach 2004-2012 (8 serii), zatytułowanego Dr House był zwolennik odczłowieczonej medycyny, przekraczający lekarskie normy etyczne tytułowy doktor Gregory House (High Laurie). Genialny serialowy lekarz słynął ze swej arogancji i cynizmu, ale z drugiej strony potrafił być niezwy-

na biznesmena, bezdzietna; Lynette Scavo (Felicity Huffman), indyferentna religijnie, była bizneswoman, matka czwórki dzieci; Susan Mayer (Teri Hatcher) rozwiedziona z prawnikiem, mieszka z córką; Mary Alice (Brenda Lee Strong).

${ }^{23}$ Między innymi seriale, w których pojawiły się kobiece wizerunki - lata 50. - układne gospodynie domowe: Kocham Lucy (I Love Lucy); lata 70. - pracujące, samodzielne kobiety: The Mary Tyler Moore Show, ale też kobiety „luksusowe” - Dallas, Dynastia; lata 90. - „zwyczajne dziewczyny" - Przyjaciele, oraz kobiety wyzwolone - Seks w wielkim mieście.

${ }^{24}$ K. Jachymek, Smak kobiety. Wyjaśniajac „Gotowe na wszystko”, [w:] Wtadcy torrentórw. Wokót angażujacego modelu telerwizji, pod red. M. Major i J. Bucknall-Hołyńskiej, Wydawnictwo Uniwersytetu Gdańskiego, Gdańsk 2014, s. 107.

${ }^{25}$ A. Niemczyńska, Dr House - demaskator amerykańskiej „kultury cynizmu”, [w:] Post-soap. Nowa generacja seriali telewizyjnych a polska widownia, pod red. M. Filiciaka, B. Gizy, Wydawnictwo Naukowe Scholar, Warszawa 2011, s. 74-75. 
kle skuteczny w tropieniu chorób, niczym detektyw ${ }^{26}$. Ponadto doktor House był człowiekiem zgorzkniałym, który wygłaszał rasistowskie i seksistowskie opinie, a jego charakterystykę dopełniał fakt, iż był on niepełnosprawnym narkomanem ${ }^{27}$. Społeczny kontekst, w jaki wpisywał się serial stanowiła amerykańska „kultura cynizmu”, którą charakteryzują powierzchowne relacje międzyludzkie, społeczne frustracje, uzależnienia, rasizm, brak idealizmu, odejście od wartości chrześcijańskich, ironia i obojętnośćc ${ }^{2}$. Te wszystkie cechy kultury cynizmu, o której pisali teoretycy, reprezentuje Gregory House. Popularność House'a wpisuje się w szersze zjawisko charakterystyczne dla wielu serialowych produkcji ostatnich lat. Polega ono na narracyjnej ważności wątpliwych moralnie lub wręcz nikczemnych figur, prawie zawsze chorych, tworzacych pewien serialowy trend i związany z nim typ bohatera nazywanego antybohaterem. Serialowi antybohaterowie są różni. Od aroganckiego zwierzchnika, człowieka destruktywnie pękniętego, ale moralnego, jak doktor House do absolutnie amoralnych czarnych charakterów, jak Tony Soprano. Postać antybohatera w opowiadaniu regularnie wzbudza „względną moralność”, w której budzący etyczne wątpliwości bohater jest zestawiany $z$ bardziej jednoznacznie nikczemną i niesympatyczną postacią, aby podkreślić że antybohater ma cechy pozwalające na odkupienie. Razem z Tonym Soprano i innymi wiodącymi antybohaterami z seriali widzowie stają się bardziej powiązani $z$ bohaterami o względnej moralności wewnątrz serialowego uniwersum ${ }^{29}$.

Zastanawiając się nad polskimi mitycznymi serialowymi bohaterami należy zauważyć, że w serialach polskich od lat 2000. dominują kobiece bohaterki, wcześniej, w PRL-u byli to mężczyźni ${ }^{30}$. W drugiej dekadzie lat 90. XX wieku

${ }^{26}$ W Polsce serial Dr House był emitowany, oprócz stacji kodowanych, [w:] TVN, TVN7, TVP2.

${ }^{27}$ A. Niemczyńska, Dr House - demaskator amerykańskiej „kultury”, [w:] Post-soap..., dz. cyt., s. 75 .

${ }^{28}$ Tamże, s. 76.

${ }^{29}$ J. Mittell, Complex TV. The Poetics of Contemporary Television Storytellins, New York University Press, New York and London 2015, s. 143-144.

${ }^{30}$ Por. J. Wróbel, „Zte kobiety” w polskich serialach, czyli co zamiast Matki Polki, [w:] Polskie seriale telewizyjne, wyd. cyt., s. 151. 
i w pierwszych latach wieku XXI nowym fenomenem serialowym, a także kulturowym w polskiej produkcji były telesagi rodzinne produkowane przez telewizję publiczną, takie jak: Klan (TVP1, 1997-), M jak mitośc (TVP2, 2000-), Ztotopolscy (TVP2), które bardzo szybko stały się najpopularniejszymi serialami w Polsce. Nowa symboliczna gra, jaką rozpoczęto w telesagach polegała na przepracowywaniu starych symboli dotyczących kobiecości, męskości, rodziny i nadawaniu im nowych form. Dotyczyła ona przede wszystkim bohaterów, a właściwie bohaterek. Taką wzorcową bohaterką polskich telesag rodzinnych stała się dobrze znana $z$ literatury i polskiego kina figura Matki Polki wyrażająca mit ofiary w imię wartości patriotycznych i rodzinnych. Nowa serialowa Matka Polka ma różne oblicza. Tradycyjne uosabia przedstawicielka starszego pokolenia Barbara Mostowiak (Teresa Lipowska), bohaterka serialu Mjak mitośc, która całe swoje życie całkowicie podporządkowuje rodzinie - mężowi i dzieciom. Ale są też w telesagach młodsze Matki Polki, takie jak Krystyna Lubicz (Agnieszka Kotulanka), bohaterka serialu Klan, pracownik naukowy uczelni, tłumaczka, dla której praca zawodowa jest ważna, ale najważniejsza jest jednak rodzina. Podobny wzór prezentują też przedstawicielki najmłodszego pokolenia, jak chociażby Kinga Zduńska (Katarzyna Cichopek) z M jak mitość, kobieta wykształcona $z$ powodzeniem godząca ambicje zawodowe $z$ obowiązkami rodzinnymi, przy czym wartością pierwszorzędna, podobnie jak w przypadku starszych telesagowych bohaterek, pozostaje rodzina.

W nowej polskiej produkcji serialowej mamy także swego rodzaju polską wersję Ally McBeal, przynajmniej tak serial był promowany w Polsce. Jest nią prawniczka Magda Miłowicz (Joanna Brodzik), bohaterka serialu Magda $M$. wyprodukowanego przez komercyjną stację TVN (2005-2007). W amerykańskim serialu Ally MCBeal producenci podjęli różne kontrowersyjne społecznie, ale niewątpliwie ważne tematy dotyczące kwestii etycznych, religijnych seksualnych, poddając je w ten sposób szerokiej dyskusji społecznej. Natomiast główna bohaterka Magdy $M$ wprawdzie jest prawniczką i realizatorzy od czasu do czasu pokazują ją na sali sądowej, ale nie wiąże się to z podjęciem jakichś istotnych kwestii prawnych czy społecznych. W polskiej wersji skoncentrowano się na miłosnych perypetiach bohaterki pokazanych w telenowelowej konwencji. 
Głównym celem polskiej kobiety wyzwolonej, za jaką chce uchodzić Magda M., pozostaje wyjście za mąż i posiadanie dzieci. Być może „przyczyn takiego stanu rzeczy należy upatrywać w tym, że w Polsce nie zostały symbolicznie „przerobione" ani pierwsza, ani druga fala feminizmu - my od razu przeszliśmy do trzeciej, przyprawionej wciąż romantyczno-patriarchalno-konfesyjnym sosem, który powoduje, ze kobiece bohaterki są obecne, lecz nadal zdają się wpisywać w tradycyjny wzorzec, wedle którego pełnię kobiecości można odnaleźć dopiero przy boku ukochanego i w wypełnianiu społecznej roli matki”31. Polski odpowiednik wzoru kobiety wyzwolonej, realizującej postfeministyczny model kobiecości realizują, co ciekawe, kobiety w średnim wieku porzucone przez mężów, bohaterki takich seriali, jak: Ja wam pokaże, Przepis na życie, Dom nad rozlewiskiem. W trudnej sytuacji życiowej, w jakiej się znalazły zaczynają się one realizować zawodowo i prywatnie. Bohaterki te nie zyskały jednak w Polsce takiego społecznego oddźwięku, jak bohaterki telesag rodzinnych.

Polską wersję mitu emancypacyjnego kobiet prezentuje „Amerykanka” Lucy, bohaterka serialu Ranczo produkowanego przez telewizję publiczną (TVP1) od 2006 roku i cieszącego się niesłabnącym powodzeniem u publiczności. Przyjechała ona do Polski z USA i osiedliła się w dworku odziedziczonym po babci we wsi Wikowyje na wchodzie Polski, na Podlasiu. W ten sposób Lucy została wpisana we wciąż nośną w Polsce symbolikę panny z dworku”. Ale Amerykanka jest kobietą nowoczesną, „stanowi ucieleśnienie siły i oświeconej kobiecości”, jak napisała Janina Falkowska ${ }^{32}$. Lucy z czasem zostaje wójtem i staje się symbolem modernizującej się i europeizującej się polskiej prowincji, ale też jest żoną i matką. W Ranczo znajdujemy także interesującego męskiego bohatera. Jest nim mąż Lucy - Kusy, wcześniej opiekujący się dworkiem niestroniący od alkoholu artysta malarz. Twórcy wykreowali Kusego jako wzór nowego mężczyzny XXI wieku stworzonego po medialnie przetworzonym kryzysie męskości, jaki miał miejsce w Polsce w latach 90. XX wieku. Kusy nadal posiada tradycyjne cechy „pa-

${ }^{31}$ A. Lewicki, dz. cyt., s. 168.

${ }^{32}$ J. Falkowska, Dydaktyczne trendy w polskiej telewizji w okresie przemian zwiqzanych z wejściem Polski do Unii Europejskiej. Procesy adaptacji do zmieniajacych się czasów ukazane w serialu „Ranczo", [w:] Polskie seriale telewizyjne, wyd. cyt., s. 256. 
triarchy”, ale jednocześnie jest czułym i wrażliwym człowiekiem, w pewnym sensie „kobiecym”.

Wyraziste wzorce męskich bohaterów w polskiej produkcji serialowej możemy znaleźć w popularnych także w naszym kraju serialach medycznych. Lekarze będący bohaterami amerykańskich seriali to geniusze, półbogowie, w polskich to jedynie profesjonaliści. Szczególnie dwie postaci urastają do rangi postaci zmityzowanych: dr Paweł Lubicz (Tomasz Stockinger), chirurg plastyczny, bohater telesagi Klan oraz dr Jakub Burski (Artur Żmijewski), bohater serialu Na dobre i na zte pracujący w szpitalu w Leśnej Górze, o jakim moglibyśmy jedynie marzyć. Obaj bohaterowie prezentują wartości, których w polskich realiach często brakuje lekarzom. Są oni wybitnymi specjalistami, ale też autorytetami, nie tylko w sensie medycznym, posiadającymi wiedzę, doświadczenie zawodowe i co szczególnie istotne, charakteryzującymi się właściwą postawą moralną. Seriale polskie, takie jak Klan czy Na dobre i na zte pokazują lekarzy i szpitale jako osobny świat zupełnie niepowiązany z polską rzeczywistością. Istotnym jego elementem, skłaniającym do zastanowienia, może być projekcyjny mit polskiego lekarza i dobrego szpitala, jakie w nich odnajdujemy.

\section{Wnioski:}

Ponieważ widzowie $z$ reguły wybierają seriale wpisujące ich w jakąś wspólnotę symboliczną, próbowałam odpowiedzieć na pytanie, o czym nam mówią popularne serialowe mity i jakie wspólnoty się wokół nich tworzą. Z szerokiej oferty stacji telewizyjnych w okresie przełomu XX i XXI wieku polscy widzowie wybierali seriale, których bohaterowie prezentują kilka ponowoczesnych mitów. Jednym z nich jest mit profesjonalisty (Mulder i Scally, Ally McBeal, Dr Gregory House, Magda Miłowicz, dr Paweł Lubicz oraz dr Jakub Burski). Z przedstawionych analiz wynika, że w amerykańskich serialach koncentracja na pracy zawodowej stanowi najwyższą wartość w życiu bohaterów, którzy starają się być, przede wszystkim, efektywni i wydajni. Profesjonalizm omawianych bohaterów wpisuje się w panującą w pierwszych dekadach XXI wieku w USA monokulturę ekonomii, o której pisała Flora Michaels. Ekonomiczna opowieść, zdaniem autorki, stała się wówczas dominującą kulturową narracją kształtującą podstawowe 
sfery życia ludzkiego, takie jak: praca, relacje międzyludzkie i środowisko naturalne, społeczeństwo, zdrowie fizyczne i psychiczne, edukacja, twórczośćc ${ }^{33}$. Natomiast $\mathrm{w}$ rodzimych produkcjach serialowych $\mathrm{z}$ przełomu wieków, zbiegających się z czasem przemian politycznych i społecznych w Polsce, mit profesjonalisty ma charakter projekcyjny, wydaje się być swego rodzaju cytatem profesjonalizmu bohaterów seriali amerykańskich. Polscy bohaterowie, pomimo deklaratywnego profesjonalizmu jako istotnej $\mathrm{w}$ ich życiu wartości, koncentrują się przede wszystkim na rodzinie.

Równie istotny w produkcji serialowej przełomu XX i XXI wieku, zarówno amerykańskiej, jak i polskiej, jest kreujący symboliczne wspólnoty widzów mit kobiety wyzwolonej. Wykreowany postfeministyczny model kobiety w omawianych serialach występuje w kilku wariantach i odzwierciedla trwające dyskusje na temat pozycji kobiety we współczesnym społeczeństwie. Jeden z nich tworzą wykształcone singielki, bohaterki seriali amerykańskich i polskich (Ally McBeal, Carry Bradshow i jej koleżanki, Magda Miłowicz), dla których kobiecość oznacza swobodę seksualną i możliwość samorealizacji zawodowej. Przy czym bohaterki omawianych polskich seriali nie są tak wyzwolone seksualnie, jak bohaterki seriali amerykańskich. Inny wariant postfeministycznego modelu kobiety stanowi mit emancypacyjny, który w amerykańskiej serialowej wersji występuje jako zdekonstruowany mit gospodyni domowej przedstawiony w serialu Desperate Housewives. Serialowa dekonstrukcja tradycyjnego wyobrażenia kobiecości polega na zakwestionowaniu roli kobiety ograniczanej do bycia żoną, matką i strażniczką domowego ogniska oraz pokazaniu jej osobistych pragnień i aspiracji. Polską wersją mitu emancypacyjnego kobiet może być Lucy, bohaterka serialu Ranczo, uosabiająca polski mit kobiety wyzwolonej, podobnie jak bohaterki seriali: Ja wam pokaże, Przepis na życie, Dom nad rozlewiskiem. Wersją mitu emancypacyjnego kobiet może być także figura Matki Polki charakterystyczna dla polskich telesag rodzinnych uosabiana przez Krystynę Lubicz, Kingę Zduńską. Nowy serialowy mit Matki Polki wykreowany w polskich telesagach rodzinnych niewiele ma wspólnego z mitem gospodyni domowej, ponieważ w polskich se-

${ }^{33}$ F.S. Michaels, Monoculture. How One Story is Changing Everything, Red Clover Press 2011, s. 4. 
rialach, nie tylko w telesagach, ich w zasadzie nie ma. Bohaterki polskich telesag są wykształcone, pracują zawodowo, a poza tym perfekcyjnie zajmują się domem.

$Z$ przedstawionych analiz wynika, że zarówno polska telewizja publiczna, jak i stacje komercyjne w Polsce emitujące w omawianym okresie seriale amerykańskie przekazywały podobny zestaw wartości. Natomiast specyfikę serialowej produkcji polskiej stanowiły realizowane przez TVP telesagi rodzinne, które oferowały widzom nowy mit kobiecości i szerzej rodziny, skutecznie konkurujące $\mathrm{w}$ przestrzeni medialnej z innymi, głównie amerykańskimi mitami. Wojciech Burszta proponuje mówić o przełomie XX i XXI wieku jako „o Erze Refleksyjności (...) Refleksyjność zakładała świadome kształtowanie tożsamości, takich zwłaszcza, które będą „wydajne” i na tyle elastyczne, aby sprostać wyzwaniom neoliberalnego modelu życia"34. Wydaje się, iż przytoczona antropologiczna diagnoza znajduje potwierdzenie w przedstawionych analizach.

\section{TV SERIES AS SYMBOLIC COMMUNITIES}

\section{Summary}

The object of consideration in this article are TV series present on the Polish media market, produced since the 1990s until today. The series are both American and Polish. In this article they are considered as symbolic communities. I scrutinize the characters presented in each of the series to demonstrate that they impersonate television myths belonging to a wider symbolic process of creating television mythologies. By conceiving series' characters as symbolic constructions I attempt to answer the question, what those popular series myths tell us and what kind of communities emerge around them.

Key words: TV series, symbolic community, lead role, main character, myth.

Słowa kluczowe: serial telewizyjny, wspólnota symboliczna, bohater serialu, mit.

${ }^{34}$ W.J. Burszta, „Bycie w ruchu” jako strategia reinwencji, [w:] Kultura pragnień $i$ horyzonty neoliberalizmu, pod red. W.J. Burszty i A. Kisielewskiego, Wydawnictwo Nauka i Innowacje, Poznań 2015, s. 34. 


\section{Bibliografia}

N. Abercombie, Television and Society, Polity Press, Cambridge, 1997.

Roland Barthes, Mitologie, przet. A. Dziadek, Wyd. KR, Warszawa 2000.

J. Bohdziewicz, Piekno aktualności.Telewizja bycia u progu czasu, NCN, Warszawa 2014.

E. Cassirer, Esej o cztowieku. Wstęp do filozofii kultury, przel. A. Staniewska, Czytelnik, Warszawa 1998.

Kultura pragnień $i$ horyzonty neoliberalizmu, pod red. W.J. Burszty i A. Kisielewskiego, Wydawnictwo Nauka i Innowacje, Poznań 2015.

F.S. Michaels, Monoculture. How One Story is Changing Everything, Red Clover Press 2011.

J. Mittell, Complex TV. The Poetics of Contemporary Television Storytellins, New York University Press, New York and London 2015.

Polskie seriale telewizyjne, pod red. P. Zwierzchowskiego, B. Gizy, J. Batesa, K. Kosińskiej, Wydawnictwo Uniwersytetu Kazimierza Wielkiego, Bydgoszcz 2014.

Post-soap. Nowa generacja seriali telewizyjnych a polska widownia, pod red. M. Filiciaka, B. Gizy, Wydawnictwo Naukowe Scholar, Warszawa 2011.

Telewizja w badaniach wspótczesnych, pod red. R. C.Allena, przeł. E. Stawowczyk, Wydawnictwo Szumacher, Kielce 1998.

Wtadcy torrentórw. Wokót angażującego modelu telewizji, pod red. M. Major i J. BucknallHołyńskiej, Wydawnictwo Uniwersytetu Gdańskiego, Gdańsk 2014.

dr hab. Alicja Kisielewska, prof. UwB

Zakład Wiedzy o Kulturze UwB 